\section{Horticulture Industry Adoption of Biodegradable Containers}

\author{
Bethany A. Harris ${ }^{1}$, Wojciech J. Florkowski², \\ and Svoboda V. Pennisi ${ }^{3}$
}

ADDITIONAL INDEX WORDS. grower, landscape service provider, plantable container, survey

SUMMARY. Biodegradable containers of various types are available on the market and can be directly purchased by growers and homeowners. However, adoption of these containers has been slow, limiting their potential as an alternative to plastic containers. It is crucial to assess level of knowledge and use of biodegradable containers by horticultural growers and landscape service providers to help explain their slow rate of adoption by the industry. An online survey instrument was implemented to assess grower and landscaper knowledge and familiarity regarding biodegradable containers in the state of Georgia. Results indicated that $83 \%$ of horticultural growers do not purchase biodegradable containers. However, peat biodegradable containers were primarily purchased when these containers were used. Both growers and landscape service providers "neither agreed nor disagreed" that the use of biodegradable containers could improve plant growth. Growers "did not know" if using biodegradable containers "improved water efficiency." Landscape service providers exhibited low knowledge of the wide variety of biodegradable containers available on the market as well as limited awareness of features of such containers as they pertained to plant growth.

$\mathrm{T}$ The U.S. Environmental Protection Agency reported that the rate of plastic waste recycling was only $9.1 \%$ in 2015 (U.S. Environmental Protection Agency, 2017). Four billion container/plant units are produced by the container crop industry annually in the United States, with petroleum-based plastic containers accounting for 1.6 billion pounds of plastic (Schrader, 2013). Moving toward sustainability, the

Received for publication 27 Dec. 2019. Accepted for publication 3 Mar. 2020

Published online 3 April 2020.

${ }^{1}$ Callaway Gardens, P.O. Box 2000, Pine Mountain, GA 31822

${ }^{2}$ Department of Agricultural and Applied Economics, 1109 Experiment Street, University of Georgia, Griffin, GA 30223

${ }^{3}$ Department of Horticulture, 1109 Experiment Street, University of Georgia, Griffin, GA 30223

We thank Sheri Dorn and Cesar Escalante for reviewing the manuscript and providing constructive criticism. We also appreciate Laura Alfonso, Amanda Hollar, and Harvey Witt for their assistance with the preparation of the manuscript. This paper is a portion of a dissertation submitted by B.H., in partial fulfillment of a Doctor of Philosophy degree. Mention of a trademark, proprietary product, or vendor does not constitute a guarantee or warranty of the product and does not imply its approval or the exclusion of other products or vendors that also may be suitable.

B.A.H. is the corresponding author. E-mail: bpennisi@uga.edu.

This is an open access article distributed under the $\mathrm{CC}$ BY-NC-ND license (https://creativecommons.org/ licenses/by-nc-nd/4.0/).

https://doi.org/10.21273/HORTTECH04563-19 green industry has shown an increased interest in biodegradable containers in the United States (Sun et al., 2015) and globally (Castronuovo et al., 2015; Zhang et al., 2019). Lower gas emissions can be achieved if alternatives to plastic containers are used; for example, Koeser et al. (2014) reported that $16 \%$ of carbon dioxide emissions of petunia (Petunia $\times$ bybrida) production are linked to the plastic containers used to grow the plants.

Traditionally, the green industry has relied on plastic containers. Plastic containers are used because of their durability, superior function, low cost, wide variety of available sizes and shapes, and ease of shipping and marketing (Chappell and Knox, 2012; Evans and Hensley, 2004; Kratsch et al., 2015). Alternative containers are made from a variety of animal- and plant-based materials that are derived from renewable sources, including bioplastics, coir, poultry feathers, processed cow manure, paper fibers, and rice (Oryza sativa) hulls (Evans et al., 2015). Biodegradable containers are typically categorized as compostable or plantable. Plantable biocontainers may be directly planted in the field, raised bed, or pots and allow plant roots to protrude through their walls. Compostable containers must be removed before planting because they degrade too slowly for plant roots to grow through the container walls. However, they decompose relatively rapidly in a compost pile (Mooney, 2009). Due to the low compression strength, alternative containers can decrease landfill space and decompose more rapidly than traditional plastic containers (Fulcher et al., 2015).

Green industry stakeholders could align with sustainability-minded consumers to potentially increase the adoption of alternative containers for landscapes (Diver et al., 2001 ). The survey of the industry regarding sustainable production practices based on a national sample yielded a $12 \%$ response rate and concluded that the primary obstacle was incompatibility of sustainable practices with the production systems used by the green industry (Dennis et al., 2010). Several other studies focused on consumers and their preferences and practices regarding sustainable gardening and choice of plant containers. Using Internet survey data, Hall et al. (2010) acknowledged seven market segments and consumer profiles regarding the characteristics of biodegradable pots and recommended idiosyncratic marketing strategies for the industry to market such containers to identified segments. Another study suggested targeting consumers with ecofriendly products in relation to the type of purchased plant (Behe et al., 2010).

The willingness-to-pay study solicited responses of consumers and used, among others, pictures of seven biodegradable containers and a plastic container made from the recycled plastic (Yue et al., 2010b). Although consumers were willing to pay a premium

\begin{tabular}{llll}
\hline $\begin{array}{l}\text { Units } \\
\text { To convert U.S. to }\end{array}$ & & & \\
SI, multiply by & U.S. unit & SI unit & $\begin{array}{l}\text { To convert SI to } \\
\text { U.S., multiply by }\end{array}$ \\
\hline 3.7854 & gal & $\mathrm{L}$ & 0.2642 \\
0.4536 & $\mathrm{lb}$ & $\mathrm{kg}$ & 2.2046 \\
6.8948 & $\mathrm{psi}$ & $\mathrm{kPa}$ & 0.1450
\end{tabular}


for several types of biodegradable pots as compared with that of the plastic pot, premium differences among specific biodegradable pots were found. A study using a mixed ordered probit model to examine the premium consumers were willing to pay for biodegradable pots yielded more accurate premium measures than the conjoint analysis and confirmed the differences in premiums across pot types (Yue at al., 2010a). Studies regarding biocontainers also included experiments involving several types of biodegradable containers and a conventional plastic pot that were evaluated with regard to the appearance and durability during production of the most widely produced potted plant, poinsettia [Euphorbia pulcherrima (Lopez and Camberato, 2011)]. The study concluded that none of the seven tested containers negatively impacted the plant appearance, but container integrity could affect marketability. Recent market research reported that ornamental plant consumers are willing to pay more for nonplastic and recyclable containers (Fulcher et al., 2015).

The use of specific biodegradable container types is influenced by many factors. The choice of container is determined by familiarity within the industry, especially in the case of novel products. Hall et al. (2010) noted that the introduction of biodegradable containers had a high level of risk and uncertainty in the green industry. The housing crisis of 2009-10 substantially lowered the home ownership rate, causing a decline in demand for the green industry products and services and caused the contraction of profits. Such developments might have slowed the interest in and the use of novel products, especially if they require the buyer to pay a premium. The degree of current knowledge about specific types of biodegradable containers bears reexamination. Such information is of interest to the manufacturers and distributors seeking ways to improve sales and to organizations interested in continuing the reduction of the use of plastic containers due to their environmental impact, limiting the amount of solid waste disposed at landfills, lessening the cost of solid waste collection, and decreasing the contamination threat to water and soil (Meng et al., 2015, 2016).
This study sought to determine the familiarity and use of biodegradable containers by plant growers and landscape professionals. Information gleaned from this research could be used to provide focused education programs to improve biodegradable container adoption. Discerning characteristics of green industry firms and respondents that are limiting or preventing the use of biocontainers identified in this study could help in the preparation of content aimed at educating industry audiences.

\section{Research on biodegradable container performance}

A number of studies of important aspects of biodegradable containers have been performed. Research has focused on three areas-water use, container integrity, and plant growth and appearance - each with direct effects on the viability of plant production and postproduction use of biodegradable containers.

WATER use. Water use by crops grown in biodegradable containers and water loss from the biocontainers themselves have been evaluated to determine if these containers have the ability to contend with petroleumbased plastic containers. Irrigation is an important aspect of container plant production and may influence the adoption of biodegradable containers. Studies have documented water loss from peat, wood fiber, straw, processed manure, rice straw, and recycled paper containers (Evans and Hensley, 2004; Koeser et al., 2013a; Nambuthiri et al., 2012), and from containers made from various mixtures of biodegradable polyester with plant fiber (Castronuovo et al., 2015). Cumulative water loss is affected by the sidewall properties; the highest rate of water loss through the container walls correlated with the highest water requirement and the lowest irrigation interval (Evans et al., 2010). High sidewall water loss has been found in wood fiber (Fertilpot; Fertil International, Boulogne-Billancourt, France), peat (Jiffy-Pot; Jiffy Products of America, Lorain, $\mathrm{OH}$ ), and processed manure (CowPot; CowPots Manufacturing and Sales, East Canaan, CT) containers, whereas low sidewall water loss has been documented in coir, rice straw, slotted rice hull containers, and bioplastic containers
(Evans et al., 2010). Under greenhouse culture, vinca (Catharanthus roseus) and impatiens (Impatiens walleriana) grown in peat-based or feather-based containers required three- or 2.5-times more water, respectively, than plants grown in plastic containers (Evans and Karcher, 2004). Water loss from plastic- and rice-hullbased containers after $8 \mathrm{~h}$ in an environment-controlled chamber under a vapor pressure deficit of $2.6 \mathrm{kPa}$ were $\approx 15 \%$ and $50 \%$, respectively (Nambuthiri et al., 2012). A large multistate study evaluated water use and plant growth in plastic and alternative nursery containers; it concluded that, in general, plants grown in wood pulp, fabric, and coir containers used more water than plants grown in plastic containers (Wang et al., 2015).

The greater evaporation rate with concomitant water loss causes higher irrigation requirements when crops are grown in biodegradable containers. Research has found that ebb-and-flood irrigation (Beeks and Evans, 2013b) and reusable plastic shuttle trays (Koeser et al., 2013b) could be viable options for conserving water when using biocontainers in greenhouse production.

Container InTEgrity. Container integrity and lifespan should be considered before the adoption of alternative containers. Greenhouse growers may experience losses as a result of plant injury if biodegradable containers are broken or torn during production, packaging, shipping, and retailing. Koeser et al. (2013b) reported that manure and peat pots have been prone to break or tear more easily, especially when wet; therefore, they require more care when handling. Peat and feather fiber containers have lower wet and dry strength compared with plastic containers (Evans and Karcher, 2004). Plastic, rice hull, coir, and recycled paper containers had the greatest wet vertical and lateral strength when compared with standard plastic containers, whereas rice straw, peat, coconut (Cocos nucifera) fiber, wood fiber, and bioplastic containers have the lowest dry punch strength (Evans et al., 2010). Low wet strength characterizes wood fiber (Fertilpot), peat (Jiffy-Pot), and processed manure (CowPot) (Zhang et al., 2019). Water absorption properties and mechanical properties of both dry and 
wet materials were found to be important for biodegradable plug trays (Schettini et al., 2013).

Greenhouse studies reported that plants grown in peat, cow manure, wood fiber, and rice straw pots could not be sold after production due to insufficient container integrity. In contrast, plants produced in plastic, rice hull, wheat starch, and recycled paper containers were sold and had unchanged container integrity after 14 weeks (Beeks and Evans, 2013b; Lopez and Camberato, $2011)$. It would appear that certain alternative container types may be effectively used in long-term crop production, whereas other types are better suited to short-term greenhouse production. Containers made of $80 \%$ plant fiber and $20 \%$ biodegradable polyester were not considered suitable for an 18-week poinsettia production cycle due to poor mechanical performance, especially breakage during handling in the marketing phase, whereas those made of $100 \%$ biodegradable polyester were comparable to plastic ones (Castronuovo et al., 2015). Biocontainer lifespan can range from a few months to several years depending on the materials, biodegradable adhesives and binding agents, resins, and waxes that are used for container production (Evans et al., 2010; Jordá-Vilaplana et al., 2017). Conneway et al. (2015) concluded that matching biocontainer type to the length of the crop cycle can be a successful strategy when using alternative containers for greenhouse crop production.

Plant appearance. The ultimate goal of plant production is a visually appealing plant. Several studies have reported enhanced or similar plant growth in impatiens, petunia, sedum (Sedum sp.), liriope (Liriope sp.), and cyclamen (Cyclamen sp.) grown in biodegradable containers as compared with those grown in plastic containers (Beeks and Evans, 2013a; Center for Applied Horticulture Research, 2010; Kuehny et al., 2011). Furthermore, Lopez and Camberato (2011) reported increased root and shoot dry weight, plant height, and bract area index of 'Eckespoint Classic Red' poinsettia grown in recycled paper when compared with plastic containers. Similarly, Castronuovo et al. (2015) reported comparable growth of poinsettia 'Premium Red' grown in alternative containers and in conventional plastic ones. Research also indicates that fiber containers have improved plant production, survival, quality, and growth because of their ability to control the substrate temperature of 'Otto Luyken' cherry laurel (Prunus laurocerasus), 'Gold Splash' wintercreeper (Euonymus fortunei), 'Cunningham's White' rhododendron (Rhododendron sp.), and 'Aztec Gold' daylily (Hemerocallis sp.), and may be effectively used to grow temperature-sensitive plants (Fulcher et al., 2012; Ruter, 1999, 2000). Kratsch et al. (2015) reported comparable to better performance of greenhouse-grown marigold (Tagetes patula), pepper (Capsicum annuum), petunia, salvia (Salvia splendens), and tomato (Solanum lycopersicum) when grown in novel biopolymer or commercially available alternative containers as compared with standard plastic ones.

The objective of this study was to probe the green industry's knowledge of biodegradable containers. Specifically, this study determined familiarity with and the use of biodegradable containers and their attributes by growers and landscape service providers and identified what attributes may prevent the adoption of biodegradable containers. Because the industry has been using plastic containers for decades, opinions about selected attributes of biodegradable containers were compared with those of plastic containers. Knowledge about biocontainers in the green industry is lacking, and the wide and continuing use of plastic containers suggests that consumer preferences have not translated into their readiness to pay for biocontainers, which may cost more than the conventional containers used by plant growers and landscape service providers.

\section{Materials and methods}

Learning about the green industry's views of biodegradable containers required reaching out directly to individual firms. Despite biodegradable containers availability on the market for quite some time, little is known about their use. This study required the collection of information about the industry opinions of and use of biodegradable containers.
Furthermore, the green industry is heterogeneous and consists of firms engaged primarily in growing plants and those that focus on the provision of landscape installation and maintenance services, suggesting a need to reach both types of firms. The list of potential survey respondents in this study was obtained from the Georgia Department of Agriculture and consisted of all firms holding a live plant license in 2017. The survey was evaluated by the University of Georgia Office of Human Subjects (STUDY 00005434) and ruled that the study did not require Internal Review Board approval because the survey targeted plant production and installation firms rather than individual survey respondents.

A draft survey was presented to several horticulture firm managers and extension specialists to assure the clarity of the questions. In addition to input from two state green industry organizations, the Georgia Green Industry Association (predominantly growers, retailers, and allied trade) and the Georgia Urban Agriculture Council (predominantly landscapers), as well as members of the Southern Nurseryman Association, we conducted detailed conversations with major landscaping companies, several major growers in Georgia, and faculty who have conducted research involving ornamental crops, and specifically those with expertise in biocontainers. Several questions about the firm business scope and other company details were inspired by previous surveys of the Georgia green industry and those found in published works (Meng et al., 2015, 2016). After the draft survey instrument was modified, an online survey instrument was created using Survey Monkey (Survey Monkey Inc., San Mateo, CA); invitations to participate were sent via e-mail to all licensed companies obtained through the Georgia Department of Agriculture. The data were collected between the first week of Apr. 2017 and the first week of Aug. 2017. A total of 14 reminders since the end of April were sent to encourage participation.

The questionnaire consisted of three parts. All respondents were invited to complete the first part, which probed for details about the firm location, scope of business operations, and size. The message placed 


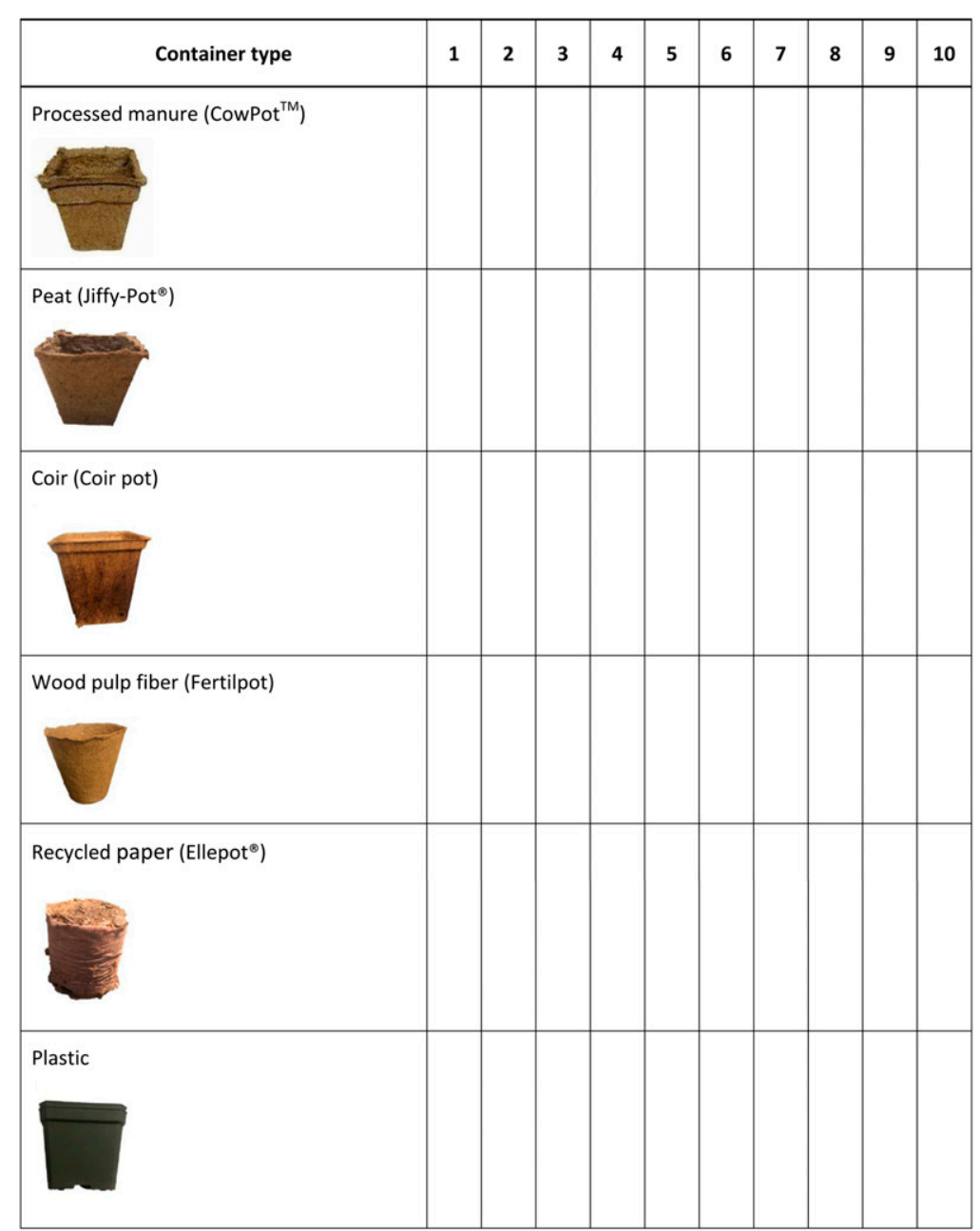

\begin{tabular}{|c|c|c|c|c|c|c|c|c|c|c|}
\hline Container type & 1 & 2 & 3 & 4 & 5 & 6 & 7 & 8 & 9 & 10 \\
\hline \multicolumn{11}{|l|}{ Coir (Coir pot) } \\
\hline $1 \mathrm{gal}$ or larger & & & & & & & & & & \\
\hline \multicolumn{11}{|l|}{ Wood pulp fiber (Fertilpot) } \\
\hline $1 \mathrm{gal}$ or larger & & & & & & & & & & \\
\hline Plastic & & & & & & & & & & \\
\hline 1 gal or larger & & & & & & & & & & \\
\hline
\end{tabular}

Fig. 1. The question presented to growers and landscape service providers who participated in a survey conducted in Georgia in 2017. The participants were requested to rate their familiarity with seven commercially available biodegradable and two sizes of plastic containers on a scale of 1 to $10(1=$ low familiarity; $10=$ high familiarity). Fertilpot (Fertil International, Boulogne-Billancourt, France), Jiffy-Pot (Jiffy Products of America, Lorain, OH), CowPot (CowPots Manufacturing and Sales, East Canaan, CT); 1 gal $=3.7854 \mathrm{~L}$. at the beginning of the second part explained that the questions were addressed to growers. Growers shared their opinions about how biodegradable containers influenced plant growth, water efficiency, and container integrity. They were also asked about types of containers used in production (Fig. 1), types of plants produced, their familiarity with growing plants in biodegradable containers, and how biodegradable containers compare with plastic containers. When a question presented a statement about a biocontainer attribute, respondents indicated their agreement by choosing an option on a scale that ranged from 1 ("strongly disagree") to 5 ("strongly agree"). An additional option allowed for an answer of "do not know."

The third part was addressed to those who installed plants in landscapes and provided maintenance services. Landscape service providers purchase plants from growers and can only choose plants in containers selected by growers. Landscapers were asked a series of statements about water use, plant growth, and container durability. As in the case of other opinion questions, respondents provided answers by choosing an option along the multistep scale. They rated their familiarity with various containers (Fig. 1) as well as their knowledge of plant performance on a scale from 1 (low) to 10 (high). The last part of the questionnaire probed for socio-demographic information about respondents, including age, gender, company position, years of schooling, and years of experience in their business area.

To gain a deeper understanding and identify characteristics of the group of respondents selecting the response option "do not know" for statements referring to attributes of biodegradable containers, a statistical test of differences in means was applied using SAS software (version 9.2; SAS Institute, Cary, NC). The Pearson's chi-squared test identified the presence of statistically significant differences between two categories of selected firm characteristics (i.e., annual revenue, number of full-time workers, and location categories) and respondent characteristics (i.e., age, education, years with the company, and position in the company). Firm and respondent characteristics 
Table 1. Survey responses of growers and landscape service providers and their opinions regarding select biodegradable container features. The first value represents the actual number of responses per feature/opinion; the second number represents the percentage of total survey responses $(\mathrm{N}=214)$. Five levels of opinion and a "do not know" option were offered to survey participants. The survey was conducted in Georgia in 2017 , and probed the knowledge and familiarity of the green industry producers and landscapers.

\begin{tabular}{|c|c|c|c|c|c|c|}
\hline & $\begin{array}{l}\text { Strongly } \\
\text { disagree }\end{array}$ & Disagree & $\begin{array}{l}\text { Neither agree, } \\
\text { nor disagree }\end{array}$ & Agree & $\begin{array}{l}\text { Strongly } \\
\text { agree }\end{array}$ & $\begin{array}{l}\text { Do not } \\
\text { know }\end{array}$ \\
\hline Biodegradable container feature & \multicolumn{6}{|c|}{ Responses [no. (\%)] } \\
\hline Improve plant growth & $4(2)$ & $16(8)$ & $77(38)$ & $24(12)$ & $13(6)$ & $60(30)$ \\
\hline $\begin{array}{l}\text { Encourage mold/fungal growth, resulting in poor } \\
\text { plant growth compared with plastic containers }\end{array}$ & $4(5)$ & $5(6)$ & $65(83)$ & $4(5)$ & - & - \\
\hline
\end{tabular}

Table 2. Survey responses of growers and their opinions regarding select biodegradable container features when compared with plastic containers. Values represent the percentage of total survey responses $(\mathrm{N}=214)$. The survey was conducted in Georgia in 2017, and probed the knowledge and familiarity of the green industry producers and landscapers.

\begin{tabular}{|c|c|c|c|c|c|c|}
\hline \multirow[b]{2}{*}{ Biodegradable container feature } & $\begin{array}{l}\text { Strongly } \\
\text { disagree }\end{array}$ & Disagree & $\begin{array}{c}\text { Neither agree, } \\
\text { nor disagree }\end{array}$ & Agree & $\begin{array}{l}\text { Strongly } \\
\text { agree }\end{array}$ & $\begin{array}{l}\text { Do not } \\
\text { know }\end{array}$ \\
\hline & \multicolumn{6}{|c|}{ Responses (no.) } \\
\hline $\begin{array}{l}\text { Biodegradable containers do not differ from } \\
\text { plastic containers in their structural integrity }\end{array}$ & 13 & 27 & 15 & 2 & - & 42 \\
\hline $\begin{array}{l}\text { Plants grown in biodegradable containers have poor } \\
\text { root development as compared with plastic } \\
\text { containers }\end{array}$ & 8 & 10 & 22 & 8 & - & 52 \\
\hline
\end{tabular}

were each classified into two groups: revenue category $(0=\leq \$ 500,000 ; 1=$ $>\$ 500,000)$, number of full-time workers $(0=\leq 10$ workers; $1=>10$ workers), location ( $0=$ non-metro location; $1=$ metro location), age categories $(0=\leq 40 ; 1=>40)$, years with the company $(0=\leq 10$ years; $1=$ $>10$ years $)$, education $(0=\leq 12$ years of schooling; $1=>12$ years of schooling), and ownership ( $1=$ owner $/$ manager, $0=$ other position). A statistically significant test value implied that the feature classified as " 1 " was more likely to occur than that classified as "0." The "metro" and "nonmetro" locations were based on the Atlanta Metro Statistical Area (AMSA) comprising 29 counties. The "metro" category was characterized by the highest population density and largest area regarding the potential residential and commercial customers of the green industry.

\section{Results}

\section{Survey respondent profile and response rate}

There were 1076 survey invitations sent to growers and landscape service providers throughout the state. Of these, 163 (15\%) respondents opted to not participate in the survey, 105 respondents $(10 \%)$ did not open the online survey instrument, 24 respondents $(2 \%)$ did not participate due to returned e-mails, and 570 respondents $(53 \%)$ opened the online survey document but did not start it. A total of 214 out of 1076 invited survey participants responded and completed the online survey, for a response rate of $20 \%$.

Among 214 survey respondents, $90 \%$ were owners or managers. The administrative staff or personnel at "other managerial" positions represented only $10 \%$ of respondents. A large share of respondents (22\%) had at least 30 years of experience in the business, but $29 \%$ had no more than 10 years of experience; another $28 \%$ had from 11 to 20 years of experience in business. Respondents were predominately male (69\%). The largest share of respondents fell into the age category of 51-60 years (30\%), followed by those older than 61 years $(27 \%)$; only $17 \%$ were 40 years old or younger, including $1 \%$ younger than
30 years. Approximately one-third $(36 \%)$ received no more than 12 years of schooling, $38 \%$ reported having 13 to 16 years of schooling, and $26 \%$ had at least 17 years of schooling. The ratio of female-to-male respondents was $\approx 1: 2$ (or $31 \%$ vs. $69 \%$ ).

\section{Biodegradable containers and plant growth opinions of all respondents (growers and landscape service providers)}

The initial question presented to all potential respondents asked for their opinion about the following statement: "Biodegradable containers improve plant growth." Plant growth, a critical factor in plant appearance, is a major objective of plant growers and landscapers who install plants in landscapes. Poor growth in the nursery impedes marketing, whereas poor growth after installation may lead to unsatisfied customer complaints, leading to potential costly replacements. The largest number of respondents $(38 \%)$ "neither agreed nor disagreed" that biodegradable containers improved plant growth, whereas 30\% chose the option "do not know" 


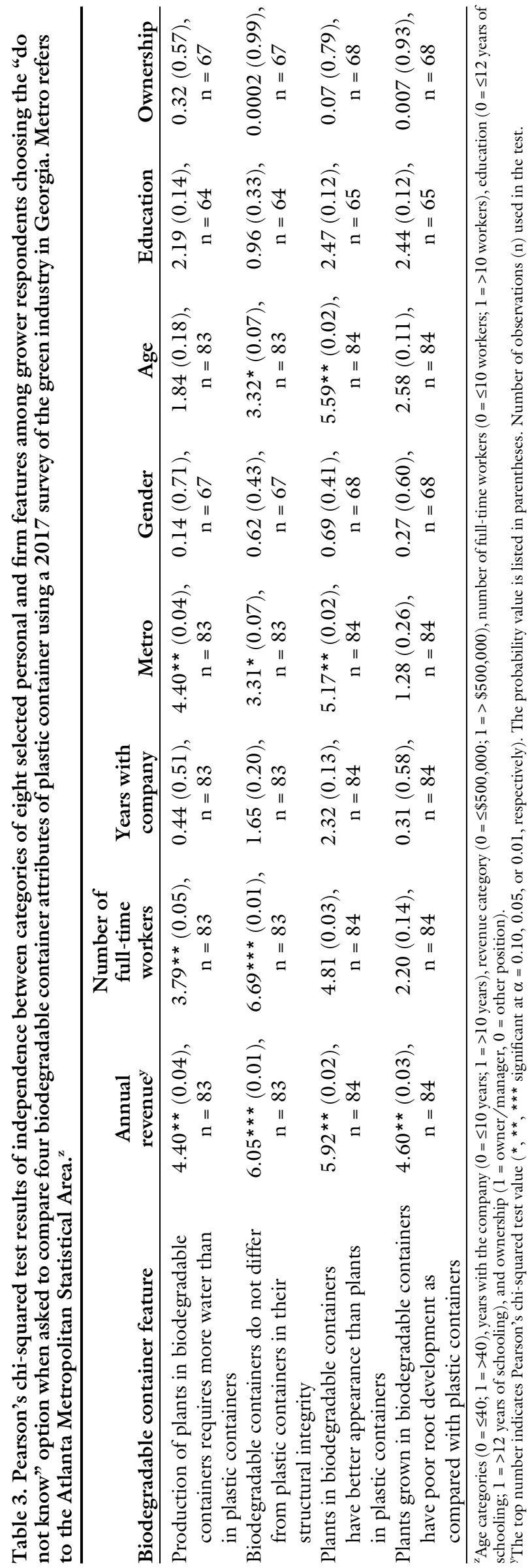

(Table 1). However, 18\% chose the response option indicating agreement with the presented statement.

\section{Plant grower opinions about biodegradable containers as compared with plastic containers}

WATER USE. When presented with the statement that "Production of plants in biodegradable containers requires more water than in plastic containers," the majority of respondents $(51 \%)$ indicated that they did not know if that was the case (Table $2)$. Although $21 \%$ chose "neither agree nor disagree" with the statement, $20 \%$ agreed with the statement. Only $7 \%$ chose to disagree, suggesting that the issue of water use is relevant, whereas the biodegradable container suppliers may want to consider the variation in water use by containers made of different natural materials and include such information when marketing to the green industry.

Container INTEgrity. Among plant growers, $40 \%$ "disagreed" or "strongly disagreed" that "Biodegradable containers do not differ from plastic containers in their structural integrity" (Table 2). This result reflects a much stronger opinion than that about water use. Almost as many $(41 \%)$ respondents felt that they did not know enough to express any opinion, and $15 \%$ "neither agreed nor disagreed."

Plant appearance. In general, the surveyed respondents did not know if biodegradable containers improved plant appearance (Table 2). As many as $44 \%$ admitted that they did not know if "Plants in biodegradable containers have better appearance as plants in plastic containers," and one out of three respondents "neither agreed nor disagreed" with this statement. Only 4\% agreed that plant appearance in biodegradable containers exceeds that in plastic containers, whereas 18\% disagreed. Another related issue is poor root growth, which affects plant appearance. A large portion of respondents $(52 \%)$ did not know if this was the case, and 22\% "neither agreed nor disagreed" that plants in biodegradable containers had poor root growth. Fewer than 1 in 10 (8\%) agreed that plants grown in biodegradable containers exhibited poor root growth. 
Table 4. Survey responses of growers and their opinions regarding issues or statements about biodegradable container performance when compared with plastic containers. Values represent the percentage of total survey responses $(\mathrm{N}=214)$. The survey was conducted in Georgia in 2017, and probed the knowledge and familiarity of the green industry producers and landscapers.

\begin{tabular}{|c|c|c|c|c|c|c|}
\hline & $\begin{array}{l}\text { Strongly } \\
\text { disagree }\end{array}$ & Disagree & $\begin{array}{l}\text { Neither agree, } \\
\text { nor disagree }\end{array}$ & Agree & $\begin{array}{l}\text { Strongly } \\
\text { agree }\end{array}$ & $\begin{array}{c}\text { Do not } \\
\text { know }\end{array}$ \\
\hline Issue or statement & \multicolumn{6}{|c|}{ Responses (no.) } \\
\hline Improve water efficiency & 5 & 10 & 34 & 7 & - & 45 \\
\hline $\begin{array}{l}\text { Allow heat dissipation from root zone } \\
\text { better than plastic containers }\end{array}$ & 5 & 4 & 29 & 27 & - & 36 \\
\hline Roots easily penetrate the container walls & 10 & 6 & 30 & 17 & - & 37 \\
\hline
\end{tabular}

DifferenCES IN FIRM AND PERSONAL CHARACTERISTICS AMONG RESPONDENTS LACKING OPINIONS ABOUT THE PERFORMANCE OF BIODEGRADABLE AND PLASTIC CONTAINERS. To encourage the use of biodegradable containers, the key attributes of the latter must be comparable to those of plastic containers; therefore, the four statements in Table 2 probed for the opinions about specific features of biocontainers as compared with those of plastic containers. However, a large percentage of the respondents (from $42 \%$ to $52 \%$ ) chose the option "do not know" for any of the four statements. Testing for statistically significant differences across firm and respondent characteristics within the group admitting they did not know if there were any differences showed striking similarities. Regarding water use, a statistically significant difference was found between firms in two revenue categories and the number of full-time workers (Table 3). Those two measures of firm size suggested that there is a difference in choosing the "do not know" option by respondents from different size firms, with respondents from large firms more likely to indicate a lack of knowledge. The response choice by firms located in the AMSA and non-metro firms were more likely to admit a lack of knowledge regarding whether plants in biodegradable containers had a better appearance than those in plastic containers (Table 3 ). Plant appearance is critical for sales and landscaping, and the dense, commercial urban environment is the largest customer of all sectors of ornamental horticulture, making this aspect an important part of any future training.

The confirmed differences in the responses to a statement comparing the structural integrity of biodegradable containers with that of plastic containers suggest that responses varied based on whether respondents worked for firms with various categories of annual revenues and the number of full-time workers (Table 3). Additionally, individuals 40 years or younger and those older than 40 years differed when choosing the "do not know" option, suggesting that the biocontainer training programs should consider the age of target participants. A significant difference in responses based on metro and non-metro locations was associated with the perception of the statement about container integrity.

The statement about biodegradable containers producing plants with a better appearance than plastic containers led to statistically significant differences across the following three features (Table 3): age, annual revenue, and location (metro vs. nonmetro). Differences in opinions regarding poor root development were identified only in the annual revenue categories.

\section{Grower opinions about biodegradable container features}

WATER USE. When asked for opinions about the ability of biodegradable plantable containers to improve water efficiency, the largest share of respondents (45\%) chose "do not know" as their response (Table 4). Another 34\% of respondents selected "neither agree nor disagree." Only 7\% agreed that such containers improved water efficiency; in contrast, 15\% "strongly disagreed" or "disagreed" that was the case.

The responses to the statement that plantable biodegradable containers allow better heat dissipation from the root zone than do plastic containers might have offset the unfavorable view regarding the water use efficiency. Only $9 \%$ of respondents disagreed with that statement compared with $27 \%$ who agreed (Table $4)$. The share of those who did not know was 36\%, and 29\% neither agreed nor disagreed that, in terms of heat dissipation, plantable biodegradable containers outperformed plastic. Heated root zones may lead to substantial damage, thereby causing poor plant appearance. Still, the number of respondents who showed their lack of knowledge or chose the neutral opinion was substantial and suggested that educating the green industry may shape opinions in this regard.

Container InTEgrity. This attribute of plantable biodegradable containers was evaluated indirectly by asking the plant growers if the container walls could be easily penetrated by roots. The opinions were nearly evenly divided, with 16\% disagreeing and $17 \%$ agreeing that roots can easily penetrate the walls (Table 4 ). The share of respondents who did not know the answer was $37 \%$, and $30 \%$ chose "neither agree nor disagree" as their response.

Plant growth. Whether plantable biodegradable containers enhance plant growth is unknown; $42 \%$ of respondents admitted they did not know if that was true and another $36 \%$ chose a neutral answer (Table 4). Only 7\% of respondents agreed that such containers enhanced plant growth. Respondents who chose to disagree accounted for $16 \%$ of the sample.

Differences IN FIRM AND PERSONAL CHARACTERISTICS AMONG RESPONDENTS LACKING OPINION ABOUT BIODEGRADABLE CONTAINERS. A substantial portion of respondents indicated a lack of opinion about the attributes of biodegradable plantable containers (from $36 \%$ to $45 \%$ ) (Table $4)$, thus suggesting the need for 


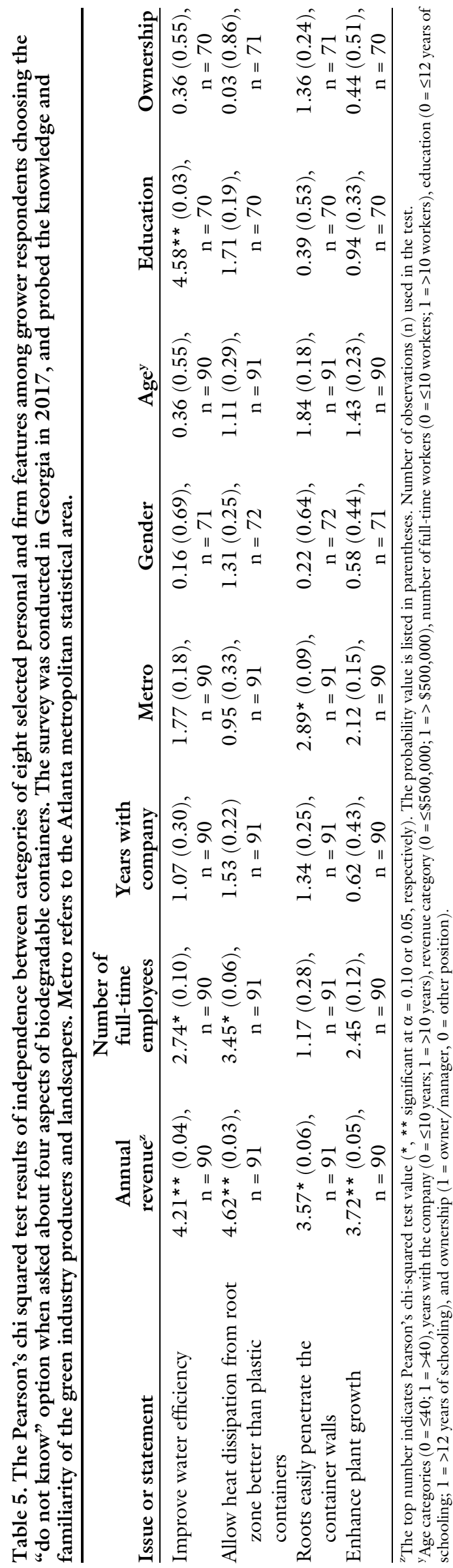

training of the ornamental green industry to allow informed choices and possibly encourage biocontainer adoption. From the viewpoint of the trainer, characteristics that assist in channeling efforts at workshops and practical demonstrations involve the firm and respondent features (Table $5)$. Because the share of respondents selecting the option "do not know" varied (Table 4 ), the important features associated with the indicated lack of knowledge could vary as well.

In the case of opinions regarding the use of biodegradable plantable containers improving water efficiency, three factors distinguished that group, as shown by the significant test results (Table 5). Choosing the "do not know" option varied based on whether respondents were from firms classified as reporting $\$ 0.5$ million or firms with annual revenues exceeding that amount. Furthermore, choosing the "do not know" option varied based on the number of full-time employees (no more than 10 fulltime workers vs. more than 10 fulltime workers) (Table 5). The education level of respondents was also associated with statistically significant differences in choosing the "do not know" response option. Those with more than 12 years of education were more likely to select the option "do not know" compared with those with a less education.

When asked about the ability of biodegradable containers to dissipate heat around roots, two firm feature (revenue category and the number of full-time employees) were associated with significant differences when choosing the "do not know" response option. Because a similar result was found for water use efficiency, these two firm features are of particular importance and indicate a lack of knowledge among large firms regarding biocontainers.

Revenue category was a differentiating factor among respondents who selected the "do not know" option when asked if biodegradable container walls were easily penetrated by roots (Table 5 ). The metro location, with its concentration of actual and potential customers, creates conditions that offer opportunities to try novel containers; this feature was statistically significant 
Table 6. Types of plants produced in biodegradable containers as reported in a 2017 survey of growers and landscapers. Values represent the percentage of the total survey responses $(\mathrm{N}=214)$. The survey was conducted in Georgia in 2017 , and probed the knowledge and familiarity of the green industry producers and landscapers.

\begin{tabular}{|c|c|c|c|c|c|}
\hline \multirow[b]{2}{*}{ Plant type ${ }^{\mathrm{z}}$} & Almost never & Seldom & $\begin{array}{c}\text { Neither often, } \\
\text { nor seldom }\end{array}$ & Often & Very often \\
\hline & \multicolumn{5}{|c|}{ Responses (no.) } \\
\hline Annuals & 69 & 9 & 6 & 12 & 4 \\
\hline Herbaceous perennials & 75 & 4 & 6 & 13 & 1 \\
\hline Shrubs (1 gal $^{\mathrm{z}}$ or larger $)$ & 86 & 2 & 6 & & 3 \\
\hline Ornamental trees ( 1 gal or larger) & 88 & 2 & 5 & 3 & 3 \\
\hline Ornamental shrub or tree liner & 82 & 5 & 5 & 6 & 3 \\
\hline Edible vines & 86 & 2 & 8 & 3 & 2 \\
\hline
\end{tabular}

${ }^{\mathrm{z}} 1 \mathrm{gal}=3.7854 \mathrm{~L}$.

Table 7. Survey responses of landscape service providers regarding issues or statements about biodegradable container performance when compared with plastic containers. Values represent the percentage of total survey responses $(\mathrm{N}=214)$. Five levels of opinion and a "do not know" option were offered to survey participants. The survey was conducted in Georgia in 2017, and probed the knowledge and familiarity of the green industry producers and landscapers.

\begin{tabular}{|c|c|c|c|c|c|c|}
\hline & $\begin{array}{l}\text { Strongly } \\
\text { disagree }\end{array}$ & Disagree & $\begin{array}{c}\text { Neither agree, } \\
\text { nor disagree }\end{array}$ & Agree & $\begin{array}{l}\text { Strongly } \\
\text { agree }\end{array}$ & $\begin{array}{c}\text { Do not } \\
\text { know }\end{array}$ \\
\hline Issue or statement & \multicolumn{6}{|c|}{ Responses (no.) } \\
\hline $\begin{array}{l}\text { Plantable containers easily break when handled } \\
\text { at installation sites }\end{array}$ & 2 & 4 & 39 & 15 & - & 40 \\
\hline Plants grow better after installation & 4 & 9 & 30 & 14 & - & 40 \\
\hline
\end{tabular}

regarding the "do not know" option chosen by respondents from metro and non-metro companies. Finally, only one of the two annual revenue categories was found to be significant when answering questions about whether biodegradable containers enhanced plant appearance.

GROWER USE AND FAMILIARITY WITH TYPES OF BIODEGRADABLE CONTAIners. Plant growers who use biodegradable containers already select only some plant varieties to grow in them and avoid using them for growing all plants. Annuals, herbaceous perennials, and vegetables were grown "often" or "very often" by $16 \%, 14 \%$, and $22 \%$, of respondents, respectively, who used biodegradable containers (Table 6). In contrast, shrubs, ornamental trees, fruit trees, and edible vines were "almost never" grown in biodegradable containers by $86 \%, 88 \%, 86 \%$, and $86 \%$ of respondents, respectively. The difference in the use of biodegradable containers with regard to the plant type can be explained by the period required to grow a plant to a commercial size. Plants that are marketed in the season when they were planted are more often grown in biodegradable containers.
The biodegradable nature of a container makes it potentially unsuitable for multi-year production cycles, but annuals or vegetable plants in biodegradable containers may appeal to retail customers by offering reasonable marketing opportunities.

Survey respondents were also asked to identify types of biocontainers familiar to them. From the list containing six specific biodegradable containers and a category "other," growers most frequently selected peat containers [36 respondents (17\%)], coconut coir $[16(7 \%)]$, and recycled paper containers $[11(5 \%)]$, followed by the container made from processed cow manure [8 (4\%)].

\section{Opinions of landscape service providers}

For landscapers, the structural integrity of a plant container is of immediate interest because plants have to withstand transportation to the installation site. Another important attribute is the appearance or growth of the installed plant. Water use is less of an issue because the cost of irrigation is the responsibility of the owner of the landscape, not the landscaper, although if plants are under landscaper's care before planting for an extended time, then plant quality may be negatively impacted by inadequate watering.

Container integrity. The statement presented to the landscapers was "plantable containers easily break when handled at installation sites"; there were six response options, including "do not know" (Table 7). Similar to a pattern of responses observed previously, $40 \%$ of respondents indicated that they did not know enough to select any other response option. A nearly identical share, 39\%, chose "neither agree nor disagree," suggesting that the biocontainers may not be outperformed by plastic containers in this regard. However, $15 \%$ of respondents agreed that biocontainers could easily break vs. $6 \%$ who disagreed.

Plant growth. Because plant growth is crucial for the intended appearance, the landscape professionals were presented with the statement directly addressing this aspect and asked to provide their opinion of whether "plants grow better after installation" if they are in plantable containers. The responses were somewhat different from those regarding 
Table 8. Types of installed plants as reported in a 2017 survey of growers and landscapers. Values represent the percentage of total survey responses $(\mathrm{N}=214)$. The survey was conducted in Georgia in 2017 , and probed the knowledge and familiarity of the green industry producers and landscapers.

\begin{tabular}{|c|c|c|c|c|c|}
\hline \multirow[b]{2}{*}{ Plant type } & Almost never & Seldom & Neither often nor seldom & Often & Very often \\
\hline & \multicolumn{5}{|c|}{ Responses (no.) } \\
\hline Annuals & 30 & 12 & 10 & 27 & 21 \\
\hline Shrubs & 29 & 5 & 8 & 25 & 33 \\
\hline Ornamental trees & 29 & 11 & 7 & 22 & 31 \\
\hline Fruit trees & 54 & 21 & 13 & 7 & 5 \\
\hline Edible vines & 59 & 20 & 14 & 6 & 1 \\
\hline
\end{tabular}

Table 9. Survey responses of landscape service providers reflecting their familiarity with manufactured biodegradable containers. Values represent the percentage of total survey responses $(\mathrm{N}=214)$. Participants rated their knowledge on a scale from 1 to 10 ( 1 = low familiarity, 10 = high familiarity). The survey was conducted in Georgia in 2017 , and probed the knowledge and familiarity of the green industry producers and landscapers.

\begin{tabular}{|c|c|c|c|c|c|c|c|c|c|c|}
\hline \multirow[b]{2}{*}{ Container type } & 1 Not at all familiar & 2 & 3 & 4 & 5 & 6 & 7 & 8 & 9 & 10 Very familiar \\
\hline & \multicolumn{10}{|c|}{ Responses (no.) } \\
\hline Processed manure (CowPot) & 46 & 6 & 4 & 3 & 12 & 3 & 9 & 5 & 1 & 9 \\
\hline Coconut coir & 49 & 13 & 6 & 2 & 10 & 6 & 3 & 3 & 2 & 5 \\
\hline Wood pulp fiber (Fertilpot) ${ }^{\mathrm{z}}$ & 44 & 4 & 9 & 4 & 12 & 6 & 3 & 6 & 3 & 7 \\
\hline Recycled paper (Ellepot) & 47 & 7 & 5 & 5 & 8 & 4 & 4 & 5 & 2 & 12 \\
\hline Wood pulp fiber (Fertilpot 1 gal or larger) & 61 & 9 & 4 & 6 & 8 & 3 & 2 & 1 & 1 & 3 \\
\hline Plastic container ( 1 gal or larger) & 4 & - & 4 & 1 & 1 & - & - & 2 & 2 & 86 \\
\hline
\end{tabular}

${ }^{\mathrm{z}}$ Fertilpot (Fertil International, Boulogne-Billancourt, France), Jiffy-Pot (Jiffy Products of America, Lorain, OH), CowPot (CowPots Manufacturing and Sales, East Canaan, CT); 1 gal $=3.7854 \mathrm{~L}$.

container integrity. Although $40 \%$ of respondents selected the "do not know" option, 30\% "neither agreed nor disagreed" with the statement. Nearly even shares of respondents "agreed" (14\%) and "disagreed" (13\%) that plants grow better after installation.

TyPes OF PURChASED PLANTS. The type of purchased plants is a link to the types of containers in which various plants are produced. Growers indicated using biocontainers for the production of annuals, herbaceous perennials, and vegetables. Among landscapers, 25\% and 33\% purchase shrubs "often" or "very often," respectively, making it the most often purchased type of plant (Table 8). Ornamental trees are purchased "very often" by $31 \%$ of landscape firms and "often" by another $22 \%$. Both shrubs and ornamental trees are grown in biocontainers often by $6 \%$ and $5 \%$ of growers, respectively, thus limiting the chances that landscape professionals encounter the environmentally friendly containers.
Two other types of plants often used by landscape firms are herbaceous perennials and annuals (Table $8)$. The first plant type was "very often" purchased by 19\% of firms but "often" purchased by 35\%, respectively. Herbaceous perennials were often grown in biocontainers by $14 \%$ of plant growers. The percentages of landscape firms that purchased annuals "very often" or "often" were $21 \%$ and $27 \%$, respectively, making this type of plant most likely to be supplied in biocontainers.

F A M I L I A R I T Y W I T H BIOCONTAINERS. Landscapers' responses clustered in the middle of the 10-step scale and at both ends of the scale, but the concentrations substantially differed. The first step of the scale indicating that a respondent was "not at all familiar" with the specific type of biocontainer was selected by the largest number of respondents, except in the case of plastic containers. Only $5 \%$ of respondents indicated the lowest level of familiarity with plastic containers, and
$4 \%$ indicated a lack of familiarity with the 1-gal or larger plastic containers. Among biocontainers, the most familiar to the surveyed firms was the peat container. Although 29\% indicated they were not familiar, $20 \%$ selected the highest level of familiarity on the 10 -step scale. None of the biocontainers was broadly familiar to the respondents; other than the peat containers, recycled paper, wood pulp fiber, and processed manure containers were familiar to $10 \%$ to $14 \%$ of respondents (a sum of those selecting the ninth and tenth step on the scale). The level of familiarity with biocontainers contrasted with $75 \%$ of respondents being "very familiar" with plastic containers. In addition, $85 \%$ of respondents were "very familiar" with plastic containers larger than 1 gal.

Finally, the landscape service providers rated the plant growth in the landscape when delivered in various biocontainers and plastic containers (Table 10). Clearly, landscape professionals, in general, lack a high level of 
familiarity with the plant growth regardless of the container. Even in the case of plastic containers, only 30\% were "very familiar" with plant growth, whereas $37 \%$ had similarly high familiarity with the growth of plants from plastic containers that were at least $1 \mathrm{gal}$ in size. These figures were considerably smaller than those indicating the level of familiarity with the container itself (Table 9). Ratings regarding plant growth if a plant originated from any type of biocontainer were concentrated in the bottom half of the 10-step scale. The three types of containers, namely, those manufactured from the processed manure, recycled paper, or peat, were rated noticeably higher than those made from other types of biodegradable material.

\section{Discussion}

Biodegradable containers offer an opportunity to reduce the use of plastic containers by the horticultural industry and lessen the adverse effects of plastic on the environment. This study aimed at investigating the opinions, familiarity, and use of biodegradable containers by growers and landscape professionals by using a list of licensed firms in Georgia. The study emphasized three important container attributes guided by previous research that examined biodegradable containers and their water use, structural integrity, and plant growth or appearance. Furthermore, the study recognized the inherent heterogeneity of the green industry and reported the opinions of growers and landscape installation and maintenance sectors separately. The results of the study indicated that reluctance to more widely adopt biodegradable containers may be attributed to previously established and persistent business relationships between plant suppliers and landscape service providers. This established business relationship may create a certain inflexibility for the landscape service provider and prevent changes to plant suppliers that do produce in biodegradable containers.

Despite the number of studies reported in the literature about various aspects of biodegradable containers, the results from the survey showed that growers generally lack knowledge about the specific aspects of container performance. Water use, which is an essential production input and cost item, was expected to be of relevance to the industry. However, the survey results revealed that, at least in the state of Georgia, the majority of responding firms did not have knowledge of how the use of biocontainers affects water use. Only slightly fewer respondents admitted not knowing how biocontainers influence the plant appearance and growth or the structural integrity of containers. Overcoming barriers such as a lack of knowledge is the first task that needs to be accomplished to encourage the use of biocontainers. Manufacturers need to undertake efforts to educate the industry and continue to use the results of publicly available research originating from, among others, land grant universities.

Growers indicated that, in general, they were not familiar with any of the seven types of biodegradable containers. Those who were familiar were in minority; in some cases, they represented less than $10 \%$ of responding firms. Among respondents who were familiar with biocontainers, a relatively larger number indicated familiarity with containers made from peat, recycled paper, and cow manure. It appears that biocontainer manufacturers do not reach the green industry with their promotional message. It is plausible that manufacturers do not have a dearth in demand or lack incentives to encourage the broader use of biocontainers. However, some types of biocontainers lacked almost any recognition among the responding firms in this study.

It appears that growers who use biocontainers only use them for growing specific types of plants, mostly annuals and vegetables, although some also grew herbaceous perennials. There is the potential for the use of compostable, not plantable, containers for the production of shrubs or ornamental trees because the former type can remain intact for more than a single growing season. The limited research of the performance of such containers over multiple growing seasons may be the reason for their sparse use. The use of plantable containers for singlegrowing-season plants signals that the green industry selects the container that suits the production conditions and meets the expectations of the buyer. Regardless, $80 \%$ of respondents reported using plastic containers. The cost of biocontainers may also discourage their use in a very

Table 10. Survey responses of landscape service providers reflecting their ratings of plants grown in commercially available manufactured containers. Values represent the percentage of total survey responses $(\mathrm{N}=214)$. Participants rated their knowledge on a scale from 1 to 10 ( $1=$ low familiarity, $10=$ high familiarity). The survey was conducted in Georgia in 2017 , and probed the knowledge and familiarity of the green industry producers and landscapers.

\begin{tabular}{|c|c|c|c|c|c|c|c|c|c|c|}
\hline \multirow[b]{2}{*}{ Container type ${ }^{z}$} & 1 Not at all familiar & 2 & 3 & 4 & 5 & 6 & 7 & 8 & 9 & 10 Very familiar \\
\hline & \multicolumn{10}{|c|}{ Responses (no.) } \\
\hline Processed manure (CowPot) & 9 & 4 & 9 & 4 & 41 & 5 & 13 & 9 & 4 & 4 \\
\hline Coconut coir & 9 & 2 & 15 & 6 & 45 & 8 & 4 & 8 & 一 & 4 \\
\hline Wood pulp fiber (Fertilpot $)^{\mathrm{z}}$ & 13 & 2 & 7 & 7 & 44 & 4 & 9 & 7 & 4 & 2 \\
\hline Recycled paper (Ellepot) & 10 & 7 & 10 & 3 & 36 & 8 & 8 & 7 & 5 & 10 \\
\hline Wood pulp fiber (Fertilpot 1 gal or larger) & 11 & 2 & 9 & 7 & 37 & 9 & 9 & 9 & 2 & 4 \\
\hline Plastic container (1 gal or larger) & 13 & - & 4 & 4 & 18 & 4 & 7 & 15 & 3 & 37 \\
\hline
\end{tabular}

${ }^{\mathrm{z} F e r t i l p o t}$ (Fertil International, Boulogne-Billancourt, France), Jiffy-Pot (Jiffy Products of America, Lorain, OH), CowPot (CowPots Manufacturing and Sales, East Canaan, $\mathrm{CT}) ; 1 \mathrm{gal}=3.7854 \mathrm{~L}$. 
competitive green industry. Brumfield et al. (2015) indicated differences in the cost per container; black plastic containers $(3.8 \mathrm{~L})$ cost $\$ 0.40$, whereas wood pulp (3.9 L) containers cost $\$ 0.62$ and fabric $(3.4 \mathrm{~L})$ containers cost $\$ 0.44$.

Landscape installation and maintenance firms purchase plants from growers and have to accept the containers used by the latter. Although landscape professionals may prefer biocontainers, they may not be willing to pay higher prices for biocontainers. The plant appearance and growth are important to landscapers; however, additional research efforts showing that plants grown in biocontainers perform at least as well as those grown in plastic containers may be warranted. Under the circumstances, the incentive for landscapers to use biocontainers more frequently could result from regulations, although it is unlikely given the already existing recycling programs. Although biodegradable containers have the potential to alleviate the environmental impact by reducing plastic waste and disposal, thereby aiding long-term sustainability, there appears a need for additional research about their performance. Landscape professionals are likely to use plastic containers because of their structural integrity. A plant is handled multiple times in a relatively short period after leaving production and before planting in the landscape. Container disintegration could cause losses for landscape firms, thus stressing the importance of structural integrity.

\section{Conclusions}

The results of this survey conducted in the state of Georgia indicate that additional education regarding the benefits of using biodegradable containers should be provided to growers to effectively lower or eliminate the barrier to the adoption of manufactured biodegradable containers (Yue et al., 2011). Horticultural firms should be educated about water use, plant growth, and ways to store and handle plants in biodegradable containers to assure that losses due to inadequate container integrity are minimized. The presented results also suggest the need to educate consumers regarding the benefits of biodegradable containers. Increases in biodegradable container demand by the consumers could accelerate their adoption.

Ultimately, overcoming barriers resulting from inadequate knowledge is essential for informed decisionmaking by green industry professionals. In addition to general information regarding the types of containers available and the benefits of producing and installing plant material grown in biodegradable containers, more focused outreach should address container degradation in the soil (important consideration for annual color installations) (Harris, 2018). Research has shown that biodegradable containers exhibit decomposition rates ranging from $18 \%$ to $88 \%$ at the end of the growing season, depending on the type of material (Sun et al., 2015) and growing conditions (Kratsch et al., 2015). The outreach also should considered certain sociodemographic aspects of the targeted audience to fine-tune its efforts. We identified that larger firms, older respondents, and those with more education were more likely to admit (by selecting the response option) that they do not have knowledge of specific issues regarding biocontainers. That makes them an easily identifiable group, but it also implies that small firms are possibly more diversified and include firms that know and do not know about those containers. Networking between and among growers and landscape service providers is one of the most efficient ways of adopting new technologies. A knowledgeable and willing landscaper with several years of experience using plants grown in biodegradable containers is well-poised to convince fellow business owners to become new adopters themselves. They should partner with such experienced industry stakeholders, manufacturers, and researchers to deliver outreach programming with the highest impact.

\section{Literature cited}

Beeks, S.A. and M.R. Evans. 2013a. Growth of cyclamen in biocontainers on an ebb-and-flood subirrigation system. HortTechnology 23:173-176.

Beeks, S.A. and M.R. Evans. 2013b. Physical properties of biocontainers used to grow long-term greenhouse crops in an ebb-and-flood irrigation system. HortScience 48:732-737.
Behe, B., B. Campbell, J. Dennis, C. Hall, R. Lopez, and C. Yue. 2010. Gardening consumer segments vary in eco-practices. HortScience 45:1475-1479.

Brumfield, R.G., A.J. DeVincentis, X. Wang, R.T. Fernandez, S. Nambuthiri, R.L. Geneve, and J.R. Stewart. 2015. Economics of utilizing alternative containers in ornamental crop production systems. HortTechnology 25:17 25.

Castronuovo, P., D. Picuno, C. Manera, A. Scopa, A. Sofo, and Y. Candido. 2015. Biodegradable pots for poinsettia cultivation: Agronomic and technical traits. Scientia Hort. 197:150-156.

Center for Applied Horticulture Research. 2010. Performance of biopots under greenhouse conditions. 21 Nov. 2015 . <http://www.cfahr.org/ 2010AnnualReport/Part9.pdf>.

Chappell, M. and G.W. Knox. 2012. Alternatives to petroleum-based containers for the nursery industry. 3 Mar. 2020. $<$ http://extension.uga.edu/publications/ files/pdf/B\%201407_1.PDF>.

Conneway, R., S. Verlinden, A.K. Koeser, M. Evans, R. Schnelle, V. Anderson, and J.R. Stewart. 2015. Use of alternative containers for long- and short-term greenhouse crop production. HortTechnology 25:26-34.

Dennis, J., R. Lopez, B. Behe, C. Hall, C. Yue, and B. Campbell. 2010. Sustainable production practices adopted by greenhouse and nursery plant growers. HortScience 45:1232-1237.

Diver, S., L. Greer, and K.L. Adam. 2001. Sustainable small scale nursery production. Natl. Sustainable Agric. Info. Serv. (ATTRA), Butte, MT.

Evans, M.R. and D.L. Hensley. 2004. Plant growth in plastic, peat, and processed poultry feather containers. HortScience 39:1012-1014.

Evans, M.R. and D. Karcher. 2004. Properties of plastic, peat, and processed poultry feather fiber growing containers. HortScience 39:1008-1101.

Evans, M.R., M. Taylor, and J. Kuehny. 2010. Physical properties of biocontainers for greenhouse crops production. HortTechnology 20:549-555.

Evans, M.R., A.K. Koeser, G. Bi, S. Nambuthiri, R. Geneve, S.T. Lovell, and J.R. Stewart. 2015. Impact of biocontainers with and without shuttle trays on water use in the production of a containerized ornamental greenhouse crop. HortTechnology 25:35-41.

Fulcher, A., G. Niu, G. Bi, M.R. Evans, T. Fernandez, R. Geneve, A. Koeser, S. 
Nambuthiri, N. Pershey, R. Stewart, S. Verlinden, and X. Wang. 2012. Assessing biocontainers and a sustainable irrigation regime for the US nursery industry. Proc. Southern Nursery Assn. Res. Conf. 57: 73-77.

Fulcher, A., D.R. Cochran, and A.K. Koeser. 2015. An introduction to the impact of utilizing alternative containers in ornamental crop production systems. HortTechnology 25:6-7.

Hall, C.R., B.L. Campbell, B.K. Behe, C. Yue, R.G. Lopez, and J.H. Dennis. 2010. The appeal of biodegradable packaging to floral consumers. HortScience 45:583591.

Harris, B.A. 2018. Critical evaluation of sustainable practices for the landscape industry. PhD Diss., Univ. Georgia, Athens.

Jordá-Vilaplana, A., A. Carbonell-Verdú, M.D. Samper, A. Pop, and D. GarciaSanogurera. 2017. Development and characterization of a new natural fiber reinforced thermoplastic (NFRP) with Cortaderia selloana (pampa grass) short fibers. Compos. Sci. Technol. 145:1-9.

Koeser, A.K., S.T. Lovell, M.R. Evans, and J.R. Stewart. 2013a. Biocontainer water use in short-term greenhouse crop production. HortTechnology 23:215219.

Koeser, A.K., G. Kling, C. Miller, and D. Warnock. 2013b. Compatibility of biocontainers in commercial greenhouse crop production. HortTechnology 23:149-156.

Koeser, A.K., S.T. Lovell, A.C. Petri, R.G. Brumfield, and J.R. Stewart. 2014. Biocontainer use in a petunia hybrid greenhouse production system: A cradle-to-gate carbon footprint assessment of secondary impacts. HortScience 49:265-271.

Kratsch, H.A., J.A. Schrader, K.G. McCabe, G. Srinivasan, D. Grewell, and W.R. Graves. 2015. Performance and biodegradation in soil of novel horticulture containers made from bioplastics and biocomposites. HortTechnology 25:119-131.

Kuehny, J.S., M. Taylor, and M.R. Evans. 2011. Greenhouse and landscape performance of bedding plants in biocontainers. HortTechnology 21:155-161.

Lopez, R.G. and D. Camberato. 2011. Growth and development of 'Eckespoint Classic Red' poinsettia in biodegradable and compostable containers. HortTechnology 21:419-423.

Meng, T., A.M. Klepacka, W.J. Florkowski, and S.K. Braman. 2015. What drives an environmental horticultural firm to start recycling plastics? Results from a Georgia survey. Res. Cons. Rec. 102:1-8.

Meng, T., A.M. Klepacka, W.J. Florkowski, and S.K. Braman. 2016. Determinants of recycling common types of plastic product waste in environmental horticultural industry: The case of Georgia. Waste Mgt. 48:81-88.

Mooney, B.P. 2009. The second green revolution? Production of plant-based biodegradable plastics. Biochem. J. 418:219232.

Nambuthiri, S., R. Geneve, T. Fernandez, A. Fulcher, A. Koeser, G. Bi, M.R. Evans, G. Niu, N. Pershey, R. Stewart, S. Verlinden, and X. Wang. 2012. Substrate heat buildup and evaporation rate differs between plastic and alternative one gallon nursery containers. Proc. Southern Nursery Assn. Res. Conf. 57:60-62.

Ruter, J.M. 1999. Fiber pots improve survival of 'Otto Luyken' laurel. Proc. Southern Nursery Assn. Res. Conf. 44:37-38.

Ruter, J.M. 2000. Biodegradable fiber containers improve the growth of two daylily cultivars. Acta Hort. 517:271-273.

Schettini, E., G. Santagata, M. Malinconico, B. Immirzi, G.S. Mugnozza, and G. Vox. 2013. Recycled wastes of tomato and hemp fiber for biodegradable pots. Res. Cons. Rec. 70:9-19.

Schrader, J. 2013. Report on the annual consumption of plastics for specialty-crop containers in the United States. 21 Nov. 2015. <http://www.public.iastate.edu/; bioplastic/Images\%20Folder/Container $\% 20$ plastics\%20estimate.pdf>.

Sun, Y., G. Niu, A.K. Koeser, G. Bi, V. Anderson, K. Jacobsen, and S.T. Lovell. 2015. Impact of Biocontainers on plant performance and container decomposition in the landscape. HortTechnology 25:63-70.

U.S. Environmental Protection Agency. 2017. Facts and figures about materials, waste and recycling. Plastics: Materialspecific data. 3 Mar. 2020. <https:// www.epa.gov/facts-and-figures-aboutmaterials-waste-and-recycling/plasticsmaterial-specific-data $>$.

Wang, X., R.T. Fernandez, B.M. Cregg, R. Auras, A. Fulcher, D.R. Cochran, and R.L. Geneve. 2015. Multistate evaluation of plant growth and water use in plastic and alternative nursery containers. HortTechnology 25:42-49.

Yue, C., C.R. Hall, B.K. Behe, B.L. Campbell, J.H. Dennis, and R.G. Lopez. 2010a. Are consumers willing to pay more for biodegradable containers that for plastic ones? J. Agr. Appl. Econ. 42:757-772.

Yue, C., C.R. Hall, B.K. Behe, B.L. Campbell, J.H. Dennis, and R.G. Lopez. $2010 \mathrm{~b}$. Investigating consumer preference for biodegradable containers. J. Environ. Hort. 28:239-243.

Yue, C., J.H. Dennis, B.K. Behe, C.R. Hall, B.L. Campbell, and R.G. Lopez. 2011. Investigating consumer preferences for organic, local, or sustainable plants. HortScience 46:610-615.

Zhang, X., C. Wang, and Y. Chen. 2019. Properties of selected biodegradable seedling plug-trays. Scientia Hort. 249:177-184. 